\title{
JPSE
}

(Journal of Physical Science and Engineering)

\section{Pendeposisian Besi pada Subtrat Alumunium dengan Metode Sputtering Terhadap Variasi Suhu}

\begin{tabular}{l}
\hline Received \\
4 November 2016 \\
Revised \\
27 December 2016 \\
Accepted for Publication \\
31 December 2016 \\
Published \\
31 December 2016 \\
\hline
\end{tabular}

\section{H. Saputro}

Program Studi Pendidikan Fisika Universitas Sarjanawiya Tamansiswa Yogyakarta, Jl. Batikan UH III/1043

*E-mail: hansputra13@yahoo.com

\begin{abstract}
The sample was a sputtered iron by aluminium substrate at variations of $60^{\circ} \mathrm{C}$ to $180^{\circ} \mathrm{C}$ with 3 hours of deposition time. The research result showed that some colour changing those partially golden yellow mix with red, blue and some of the grey. Micro-hardness was tested using MXT70 model and showed that the maximum hardness level at the temperature of $100^{\circ} \mathrm{C}$ is $113 \%$. However, at temperature $180^{\circ} \mathrm{C}$ the hardness level decreased. The resistivity and conductivity were determined by four points probe method. It was known that the resistivity decreases up to $(66 \pm 3) \times 10^{-5} \Omega / \mathrm{m}$ and the conductivity increases $(147 \pm 65)(\Omega / \mathrm{m})^{-1}$ at temperature $180^{\circ} \mathrm{C}$ and they tended to be linear and it has been the best measurement result.
\end{abstract}

Keywords: sputtering, aluminum, hardness, resistivity, conductivity.

\begin{abstract}
Abstrak
Sampel berupa besi yang disputter dengan subtrat aluminium pada variasi $60^{\circ} \mathrm{C}$ sampai $180^{\circ} \mathrm{C}$ dengan deposisi waktu 3 jam. Hasil penelitian menunjukkan adanya perubahan warna yaitu sebagian kuning keemasan bercampur merah, biru, dan sebagian lagi berwarna keabu-abuan. Uji kekerasan mikro dengan model MXT70, menunjukan tingkat kekerasan maksimum pada suhu $100^{\circ} \mathrm{C}$ adalah $113 \%$. Namun untuk suhu $180^{\circ} \mathrm{C}$ mengalami penurunan tingkat kekerasan. Penentuan resistivitas atau konduktivitas dengan metode probe empat titik. Diketahui bahwa terjadi penurunan resitivitas $\rho$ sebesar $(66 \pm 3) \times 10^{-5}$ $\Omega / \mathrm{m}$ atau kenaikan konduktivitas $\sigma$ sebesar $(147 \pm 65)(\Omega / \mathrm{m})^{-1}$ pada suhu $180^{\circ} \mathrm{C}$ yang cenderung linier dan ini merupakan pengukuran terbaik.
\end{abstract}

Kata Kunci: sputtering, aluminium, kekerasan, resistivitas, konduktivitas.

\section{Pendahuluan}

Karakteristik suatu bahan dapat ditinjau dari sifat fisisnya diantaranya kekerasan, resistivitas, konduktifitas, porositas bahan tersebut. Untuk substrat bahan jenis logam mempunyai sifat ketahanan terhadap deformasi yaitu deformasi plastic atau deformasi permanen. Sifat tersebut selanjutnya disebut sebagai kekerasan suatu bahan, antara lain kekerasan goresan (scratch hardness), kekerasan lekukan (identation hardness) dan kekerasan pantulan (rebound).

Bahan yang mempunyai sifat unggul diantaranya lapisan tipis. Aplikasi lapisan tipis di bidang mekanika bertujuan untuk meningkatkan kekerasan (hardness), ketahanan terhadap keausan dan anti korosi. Dalam pembuatan lapisan tipis terdapat sejumlah metode yang telah dikembangkan hingga saat ini yaitu implantasi ion, penyulutan ion (surface coating) serta sputtering [3].

Penggunaan metode sputtering untuk pendeposisian akan mudah menghasilkan lapisan tipis dari bahan yang mempunyai titik leleh tinggi $1345^{\circ} \mathrm{C}$ dan lapisan yang terbentuk akan mempunyai komposisi yang serupa dengan bahan pelapis [1]. Dan agak sulit jika dibentuk dengan metode implantasi ion, penyulutan ion (surface coating). Disamping itu pada metode sputtering dapat divariasi waktu, tekanan, dan suhu. 
Untuk bahan logam hanya kekerasan goresan lekukan yang banyak dipakai karena tidak merusak bahan. Angka kekerasan knoop (KHN) menunjukkan nilai beban dibagi luas proyeksi lekukan yang tidak akan kembali ke bentuk semula persamaan 1.

$$
\mathrm{KHN}=\frac{P}{L^{2} C},
$$

dengan $P$ adalah bahan yang diterapkan, $L$ adalah panjang diagonal dan $C$ adalah konstanta penumbuk.

Pada Penentuan konduktivitas listrik bahan, pengukuran yang digunakan bersifat tidak merusak bahan, cepat dan efisien. Pengukuran resistivitas bahan tersebut menggunakan Metode Probe empat titik Gambar 1. Secara umum dirumuskan seperti dalam konsep konfigurasi Wenner [4]

$$
\rho=K \cdot \frac{V}{I}
$$

dengan $K$ adalah faktor geometri, $I$ adalah arus mengalir antara probe bagian luar dan $V$ adalah tegangan terukur antara probe bagian dalam.

Resistansi $\left(R_{s}\right)$ probe bentuk garis untuk arus yang mengalir paralel dengan permukaan dapat dinyatakan dengan persamaan 3 [2], yaitu

$$
R_{s}=\frac{\pi}{\ln 2}\left(\frac{V}{I}\right)
$$

Jika ketebalan batuan $(x)$ terhadap jarak probe $(s)$ mempunyai perbandingan $(x / s)$ kurang dari 0,4 maka resistivitasnya dinyatakan dengan

$$
\rho=R_{s} \cdot x=4,5324 \cdot \frac{V}{I} \cdot x
$$

Jadi, jika pengukuran resistivitas suatu bahan dengan menggunakan probe elektrik empat titik, maka harus dikoreksi dengan faktor koreksi sebesar 4,5324 [5]. Pada penelitian sebelumnya diketahui terjadi penurunan yang lebih tajam untuk lapisan $\mathrm{S}_{\mathrm{i}} \mathrm{N}$ yang dihasilkan melalui proses sputtering pada tekanan $9,5 \cdot 10^{-2}$ torr, yaitu menjadi sebesar 0,59 mpy [6].

Pada penelitian terdahulu juga dikatakan bahwa parameter suhu terkait dengan bahan substrat mempengaruhi struktur lapisan [7]. Prinsip dasar pada teknologi lapisan tipis, matalurgi plasa yaitu pembuatan sumber ion berkecepatan tinggi yang akan berinteraksi dengan materi yang akan mengalami suatu perlakukan dan jika gas atau serbuk dimasukan diantara dua elektroda dalam ruang vakum maka ion positif akan terdorong ke depan dengan kecepatan tinggi sehingga terbentuk plasma.

\section{Metode Penelitian}

Dalam penelitian ini akan digunakan metode sputtering untuk mendeposisian lapisan tipis besi pada subtrat alumunium terhadap variasi suhu pada interval $60^{\circ} \mathrm{C}$ sampai $180^{\circ} \mathrm{C}$ dan waktu deposisi 3 jam. Pendeposisian dengan metode tersebut ditunjukkan pada Gambar 1.

Pada alat Gambar 2 terlebih dahulu dilakukan setting alat yaitu menggunakan tekanan $6.10^{-2}$ torr, arus $(I)$ 13,8 mA, tegangan $(V) 1200 \mathrm{~V}$ dan waktu deposisi 3 jam. Selanjutnya dilakukan Uji Kekerasan Mikro persamaan 1 dan uji resistivitas atau konduktivitas keeping persamaan 3 dan 4 .

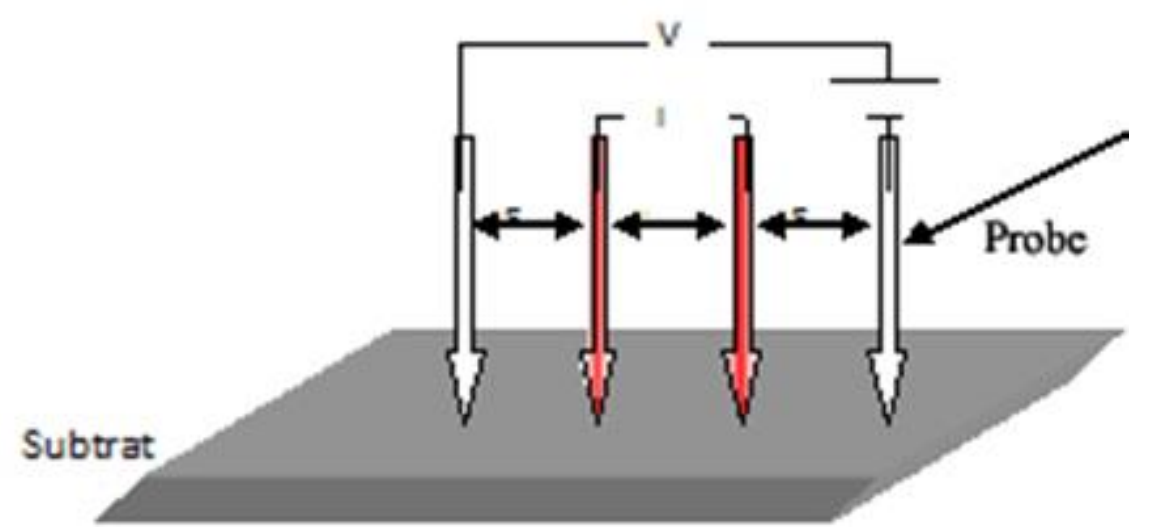

Gambar 1. Metode probe elektrik empat titik [8] 


\section{Hasil dan Pembahasan}

Pendeposisian lapisan tipis besi pada permukaan subtrat alumunium melalui proses sputtering akan mempengaruhi perubahan nilai kekerasan, resistivitas, dan konduktivitas bahan. Terlihat, bahwa subtrat alumunium yang telah dideposisi mengalami perubahan warna sebagian kuning keemasan, bercampur merah, hijau, biru, dan sebagian lagi berwarna keabu-abuan. Sedangkan subtrat aluminium masih bersih berwarna metalik. Penentuan nilai kekerasan dan resistivitas jenis untuk variasi suhu dengan tekanan $6.10^{-2}$ Torr, arus (I) $13.8 \mathrm{~mA}$, tegangan (V) $155.10^{8} \mathrm{~V}$ dan waktu deposisi 3 jam seperti ditunjukan pada tabel 1 .

\subsection{Uji Kekerasan}

Pada Gambar 3 terlihat terjadi peningkatan nilai kekerasan yang bervariasi yaitu tingkat kekerasan maksimum terjadi pada subtrat yang dideposisi pada suhu $100^{\circ} \mathrm{C}$, dengan nilai $227 \mathrm{grf} / \mu^{2}$, peningkatanya $112 \%$. Pengukuran ini merupakan pengukuran yang terbaik. Terlihat juga pada suhu $180^{\circ} \mathrm{C}$, terjadi penurunan nilai kekerasan menjadi $99 \mathrm{grf} / \mu \mathrm{m}^{2}$ dengan tingkat kekerasan $-7 \%$ yang relatif kecil dibandingkan dengan nilai kekerasan $107 \mathrm{grf} / \mu \mathrm{m}^{2}$.

\subsection{Uji Resistivitas atau Konduktivitas}

Pada Gambar 3 dan 4, terlihat peningkatan nilai konduktivitas maksimum yang terjadi pada suhu $180^{\circ} \mathrm{C}$ dengan nilai $1471\left(\Omega / \mathrm{m}^{-1}\right.$ dan pada kondisi inilah pengukuran resistivitas jenis/ konduktivitas optimal. Gambar 4 juga menunjukkan grafik konduktivitas terhadap suhu cenderung linier.

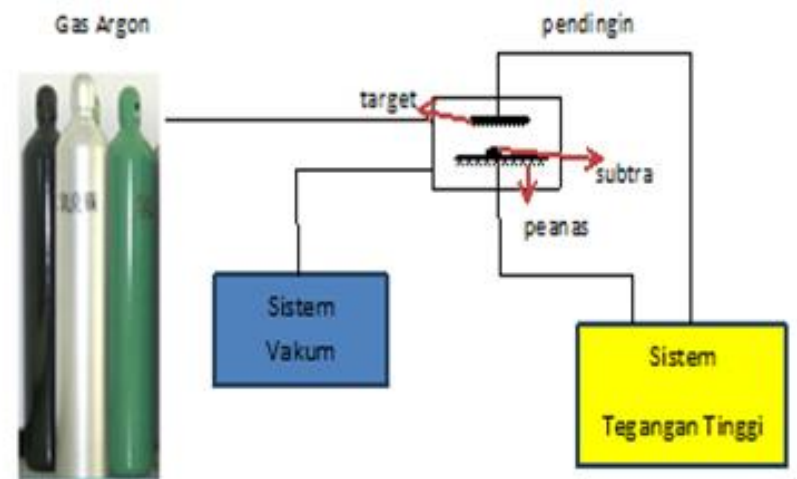

Gambar 2. Skema pendeposisian lapisan tipis dengan metode sputtering

Tabel 1. Data hasil uji kekerasan dan resistivitas untuk variasi suhu

\begin{tabular}{lcccccc}
\hline No & Cuplikan & $T\left({ }^{0} \mathrm{C}\right)$ & $\begin{array}{c}K H N \pm S_{K H N} \\
\left(\mathrm{grf} / \mu \mathrm{m}^{2}\right)\end{array}$ & $\begin{array}{c}\% K H N \\
\rho \pm S_{\rho} \times 10^{-5} \\
(\Omega / \mathrm{m})\end{array}$ & $\Omega \pm S_{\Omega}(\Omega)$ \\
\hline 1 & $\mathrm{~A}^{*}$ & 27 & $107 \pm 2$ & - & $397 \pm 4$ & $252 \pm 10$ \\
2 & $\mathrm{~B}$ & 60 & $180 \pm 5$ & 68 & $277 \pm 6$ & $361 \pm 08$ \\
3 & $\mathrm{D}$ & 80 & $204 \pm 5$ & 91 & $181 \pm 4$ & $552 \pm 12$ \\
4 & $\mathrm{E}$ & 100 & $227 \pm 2$ & 112 & $164 \pm 4$ & $609 \pm 11$ \\
5 & $\mathrm{~F}$ & 120 & $170 \pm 4$ & 59 & $143 \pm 4$ & $699 \pm 20$ \\
6 & $\mathrm{G}$ & 140 & $156 \pm 6$ & 46 & $134 \pm 3$ & $763 \pm 18$ \\
7 & $\mathrm{H}$ & 160 & $132 \pm 5$ & 23 & $104 \pm 5$ & $962 \pm 46$ \\
8 & $\mathrm{I}$ & 180 & $99 \pm 6$ & 7 & $68 \pm 3$ & $1471 \pm 65$ \\
\hline
\end{tabular}




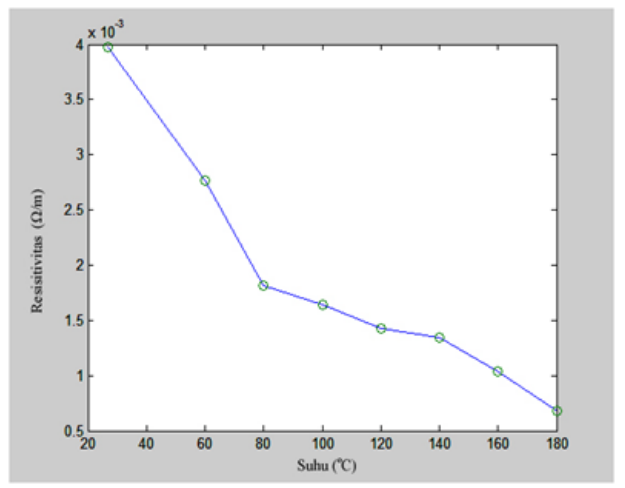

Gambar 3. Grafik resistivitas subtrat alumunium terhadap variasi suhu

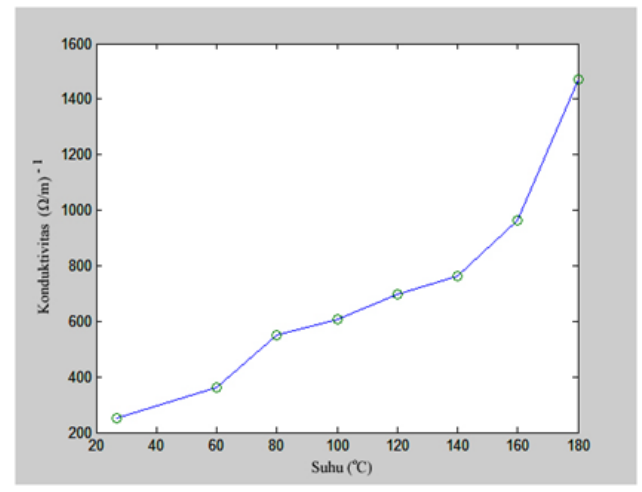

Gambar 4. Grafik konduktivias subtrat alumunium pada variasi suhu

\section{Kesimpulan dan Saran}

Pendeposisian besi pada subtrat aluminium dengan metode sputtering terhadap variasi suhu mengalami penurunan kekerasan pada suhu $180{ }^{\circ} \mathrm{C}$ sedangkan nilai resistivitas mengalami penurunan atau konduktivitas mengalami peningkatan dengan grafik cenderung linier.

\section{Ucapan Terima Kasih}

Penelitian ini dilakukan di BATAN, oleh karena itu penulis mengucapkan banyak terimakasih kepada pihak tersebut atas kepercayaannya.

\section{Daftar Rujukan}

[1] M. Konuma (1992). Film Deposition, by Plasma Techniques, Springer-Veriag. Berlin.

[2] Na Peng Bo (1995). Penelitian dan Penerapan Teknologi Lapisan Tipis Yang Di Buat Dengan PVD Untuk Pembangunan. Jurusan Fisika FMIPA Universtas Indonesia. Jakarta.

[3] M. Ohring (1992). The Materinal Science Thin Films. Academic Press. New York.

[4] M. Toifur (2014). Memahami Resistivitas Berbagai Jenis Probe Arus-Tegangan. Prosiding Pertemuan Ilmiah XXVIII HFI. Jateng-DIY.

[5] Sudjadmoko, Darsono, Djasmin (1992). Fluks Neutron $14 \mathrm{MeV}$ dari Generator Neutron sebagai Fungsi Arus Deutron. Prosiding Peresentasi dan Pertemuan Ilmiah.

[6] T. Mardji, A. Elin, N. S. Sahat (2002). Deposisi Lapisan Tipis SiN Menggunakan Teknik Sputtering untuk Pelindung Korosi pada Logam Besi. Prosiding Pertemuan Ilmiah..

[7] T. Wibowo, et al (2002). Pengaruh Parameter Sputtering terhadapn Perubahan Struktur Lapisan Tipis ZnO. Proceding P3TM, hal 166-171

[8] M. H. Looke (1999). Electrical Imaging Survey for Environemental and Engineering Studies, $A$ Practical Guide to 2-D and 3-D Surveys. Malaysia: Penang 